\title{
Fractionation of coal through organo-separative refining for enhancing its potential for the $\mathrm{CO}_{2}$-gasification
}

\author{
Heena Dhawan' ${ }^{1} \cdot$ Rohit Kumar $^{2} \cdot$ Sreedevi Upadhyayula $^{2}$ K. K. Pant ${ }^{2} \cdot$ \\ D. K. Sharma ${ }^{1}$
}

Received: 12 December 2019/Revised: 24 February 2020/Accepted: 6 July 2020/Published online: 29 July 2020

(C) The Author(s) 2020

\begin{abstract}
Coal gasification has already been extensively studied earlier under varying conditions of steam, $\mathrm{CO}_{2}, \mathrm{O}_{2}$, inert conditions. Belbaid coal and its e, N and NMP-DETA SCC products recovered through organo-refining under milder ambient pressure conditions were subjected to $\mathrm{CO}_{2}$-gasification in a fixed bed reactor under varying conditions. $\mathrm{CO}_{2}$ being an inert gas becomes the most challenging to be utilized during the gasification process. The SCCs showed better $\mathrm{CO}_{2^{-}}$ gasification reactivity than the raw Belbaid coal at $900{ }^{\circ} \mathrm{C}$. The use of the catalyst $\mathrm{K}_{2} \mathrm{CO}_{3}$ tremendously increased the gasification reactivity for both raw coal and the SCCs. The use of sugarcane bagasse for $\mathrm{CO}_{2}$-gasification along with raw coal as well as with residual coal was also studied. Gasification under $\mathrm{CO}_{2}$ atmosphere conditions was used to structurally understand the coals as the coal structure gets loosened after extraction.
\end{abstract}

Keywords Coal $\cdot$ Solvent extraction $\cdot \mathrm{CO}_{2}$ gasification $\cdot$ Catalyst

\section{Introduction}

The direct use of coal is resulting in the generation of $\mathrm{CO}_{2}$, a green house gas responsible for the climate change and consequent problems (Sharma et al. 2008). Since a large reserves of coal are available as an organic feedstock world over it is logical to think about the exploitation of coal as a source of chemicals, materials, products etc. besides of course as a cleaner fuel after refining (Sharma and Dhawan 2018). Coal is a contaminated organic feedstock, however, it is possible to produce super clean coal that is a refined coal having almost zero ash contents through separativeorgano refining techniques under milder ambient pressure contents (Dhawan et al. 2018; Sharma and Dhawan 2018). Though the process is economically not viable but this

Heena Dhawan

heena.6sep@gmail.com

1 Centre for Energy Studies, Indian Institute of Technology Delhi, New Delhi 110016, India

2 Department of Chemical Engineering, Indian Institute of Technology Delhi, New Delhi 110016, India holds a great potential for future research and later exploitation to obtain value added chemicals, materials and cleaner fuels. Recently, Sharma et al. (2019) have reported the studies on pyrolysis-GCMS of the super clean coal (SCC) obtained from the organo-refining of coals. This process can help in producing cleaner feedstocks for industrial applications in future. Separative organo refining of coal process can help in easier recovery of costly organic solvents in the direct liquefaction of SCC through hydrogenation. SCC can also be gasified to obtain syn-gas for use in the Fischer-Tropsch synthesis or for the production of methanol. Potential of the gasification of SCC in the integrated gasification combined cycle power generation has also been highlighted by Sharma and Giri (2016). Sharma et al. (2011) have reported the studies on the steam gasification of solvent extracted and pre-pyrolysed Indian coals under milder ambient pressure conditions. However, the rate of gasification of coal is controlled by the $\mathrm{CO}_{2}$ gasification reactions as these are slower than the steam-gasification reactions. Recently Sharma and Giri (2016) have reported on the $\mathrm{CO}_{2}$ gasification reactivity of separative refined Indian coals mainly through thermogravimetric analysis. Presently studies have been extended on the $\mathrm{CO}_{2}$ 
gasification reactivity of separative organo-refined coal by using a fixed bed gasification reactor.

Presently, there is a lot of stress on the reduction in the $\mathrm{CO}_{2}$ gas emissions which can mainly be achieved through strategic implementation of the methods to capture $\mathrm{CO}_{2}$ and can be used to produce valuable fuels and chemicals (Dhawan et al. 2018). One of the suggested methods include the injection of $\mathrm{CO}_{2}$ more than $90 \%$ concentration in gas or liquid stream into the oceans or underground deep geological sites (Efthymia et al. 2018; Leung et al. 2014; Schafer 1991). It may be mentioned that solar and wind energy are being exploited as cleaner forms of energy replacing coal and other fossil fuels. However, still there are concerns about the use of toxic materials such as $\mathrm{Pb}$, $\mathrm{Cd}, \mathrm{Zn}$ etc. in the manufacture of high efficiency photovoltaic cells. These cells may have to be disposed off after 20-25 years and then the management of these hazardous wastes including the wastes from batteries may also have to be tackled (Babaygit 2016).

Coal gasification is generally carried out at high temperatures $\left(<1000{ }^{\circ} \mathrm{C}\right)$ (Tomita et al. 1985; Takarada et al. 1992; Kubiak et al. 1983; Huhn et al. 1983). At these temperatures, the gasification of coal is most readily performed. The fluidized bed gasification is normally carried out at relatively lower temperatures of about $800-900{ }^{\circ} \mathrm{C}$ (Adschiri and Furusawa 1986). The use of steam offers relatively faster gasification rates, however, there is a need for the utilisation of $\mathrm{CO}_{2}$ for the obvious reasons discussed before. The following reactions (along with their $\Delta H^{\circ}{ }_{298}$ ) take place during coal gasification:

$$
\begin{aligned}
& \mathrm{C}_{\sim 90-120-240} \mathrm{H}_{\sim 6-9-20} \mathrm{O}_{\mathrm{x}} \mathrm{S} \\
& { }_{\mathrm{y}} \mathrm{N}_{\mathrm{z}}+\mathrm{O}_{2}+\mathrm{H}_{2} \mathrm{O} \rightarrow \mathrm{C}_{\mathrm{n}} \mathrm{H}_{\mathrm{m}}+\text { other products (overall } \\
& \text { endothermic reaction) } \\
& \mathrm{C}_{\mathrm{n}} \mathrm{H}_{\mathrm{m}} \rightarrow \mathrm{nC}+\mathrm{mH} \\
& \mathrm{C}+1 / 2 \mathrm{O}_{2} \rightarrow \mathrm{CO} \Delta \stackrel{\circ}{2}_{298}=+202.4 \mathrm{~kJ} / \mathrm{mol} \text { (endother- } \\
& \text { mic reaction) } \\
& \mathrm{C}+\mathrm{O}_{2} \rightarrow \mathrm{CO}_{2} \Delta \stackrel{\circ}{H}_{298}=-405.9 \mathrm{~kJ} / \mathrm{mol} \text { (exothermic } \\
& \text { reaction) } \\
& \mathrm{C}+\mathrm{CO}_{2} \rightarrow 2 \mathrm{CO} \Delta \stackrel{\circ}{H}_{298}=+159.7 \mathrm{~kJ} / \mathrm{mol} \text { (endother- } \\
& \text { mic reaction) } \\
& \mathrm{C}+\mathrm{H}_{2} \mathrm{O} \rightarrow \mathrm{CO}+\mathrm{H}_{2} \Delta \stackrel{\circ}{2}_{298}=+118.9 \mathrm{~kJ} / \mathrm{mol} \text { (En- } \\
& \text { dothermic reaction) } \\
& \mathrm{CO}+\mathrm{H}_{2} \mathrm{O} \rightarrow \mathrm{CO}{ }_{2}+\mathrm{H}_{2} \\
& (\text { exothermic reaction) } \\
& \mathrm{C}+2 \mathrm{H}_{2} \rightarrow \mathrm{CH}_{4} \Delta \stackrel{\circ}{H}_{298}=-87.4 \mathrm{~kJ} / \mathrm{mol} \text { (exothermic } \\
& \text { reaction) }
\end{aligned}
$$

Since $\mathrm{CO}_{2}$ gasifications are normally slow, therefore the enhancement in the rate is brought out with the help of a catalyst (Sun et al. 2004). The most widely used catalysts are the alkali metals (Perez-Florind et al. 1993) out of which $\mathrm{K}_{2} \mathrm{CO}_{3}$ has been most favourable. Catalysts not only help in increasing the rate of gasification but these also help in $\mathrm{H}_{2}$ production (Wang et al. 2005). The hindrance of the ash particles on the activity of the catalyst results in the reduction of the efficiency of the process. To overcome this problem, a number of coal pretreatment methods (solvent extraction and chemical leaching) to remove the ash followed by gasification have been performed on a number of coals (Sharma et al. 2008; Wang et al. 2005; Formella et al. 1986). The presence of ash has been reported to account for the loss in catalyst activity (Yoshida et al. 2002; Okuyama et al. 2004). Amongst these techniques solvent extraction of coals results in producing almost zero ash super clean coals (Sharma and Dhawan 2018).

Coal gasification has been performed under varying conditions of steam, $\mathrm{CO}_{2}, \mathrm{O}_{2}$, inert conditions. Various combinations have been used in the past to increase the rate of the gasification (Sharma and Giri 2016; Nishiyama 1986). The greater utilization of $\mathrm{CO}_{2}$ is ensured with the gasification process being performed under $\mathrm{CO}_{2}$ atmosphere. The major advantage is the reduced emission of $\mathrm{CO}_{2}$ into the atmosphere. $\mathrm{CO}_{2}$ being an inert gas becomes the most challenging to be utilized during the gasification process. However, this offers better accessibility to the coal to be gasified under $\mathrm{CO}_{2}$ conditions. From the economic point of view, low gasification temperature is desired. Group V111 metals, alkali and alkaline earth metals have been found to be the most effective catalysts for gasification of coals. In several high ash (low rank) coals, the inherent mineral matter has been observed to act as the catalyst for gasification (Calemma and Radovic 1991; Liu et al. 2003; Huang et al. 1991; Matsuoka et al. 2008; Grigore et al. 2008; Bai et al. 2009).

Most alkali and alkaline earth metals volatilize at $1000{ }^{\circ} \mathrm{C}$, therefore, lower temperatures would be required for the catalytic gasification using alkali metals. The study on the gasification of the chars at $900-1500{ }^{\circ} \mathrm{C}$ was performed by Tang et al. (2002) and they concluded that the molten ash deposited on the gasifier hinders the gasification process. Even at such high temperatures $\left(1100-1500{ }^{\circ} \mathrm{C}\right)$, the aluminosilicate melts above the ash softening temperatures and blocks the coal surface and hinders the gasification processes (Bai et al. 2009; Li 2007). The rate of gasification has been studied under varying reaction temperatures and catalyst loadings by $\mathrm{Li}$ and Cheng (1995) using $\mathrm{Na}_{2} \mathrm{CO}_{3}$ and $\mathrm{K}_{2} \mathrm{CO}_{3}$ as catalysts and found that at about $880{ }^{\circ} \mathrm{C}$, the rate of the reaction first increases with the increasing conversion and then decreases as the surface area of the char and the catalyst concentration changes. The difference in the chemical nature of the catalysts was noticed as both sodium carbonate and potassium carbonate showed different isokinetic temperature values which affected the gasification process. Ye et al. (1998) proposed the catalysed gasification rate as: $\mathrm{Na}>\mathrm{K}>\mathrm{Ca}>\mathrm{Ni}$ that affects the gasification reactivity. The mixture of the active 
actions was also tested and it was found that the individual activity of the actions is more than the combined effect. The reactivity can be controlled or varied with the presence or the absence of the actions.

Earlier studies from the author's laboratory have reported (Sharma and Singh 1996) that the organo-refining of coal using N-methyl pyrrolidone (NMP) or cetene is a beneficial treatment for the $\mathrm{CO}_{2}$ and steam gasification of coals. The $\mathrm{CO}$ produced from the $\mathrm{CO}_{2}$ gasification of coals may be utilized in the reduction of iron ore in steel plants (Chandaliya et al. 2016). In fact, it was proposed that it is much easier and cheaper to integrate IGCC power generation systems with that of $\mathrm{CO}_{2}$ storage, sequestration and utilization. Major problems in the gasifiers still arise due to the relatively high ash contents in the coals which reduces the gasification efficiency in the commercial gasifiers. Since the rate of steam gasifications is faster than that of the $\mathrm{CO}_{2}$ gasification reactions as mentioned before therefore, the latter also controls the mechanism of the gasification reactions. The $\mathrm{CO}_{2}$ gasification reactivity of NMP and cetene extracted SCC was found to be high (Sharma and Giri 2016). Even the $\mathrm{CO}_{2}$ gasification reactivity of the residual coals obtained from the solvent extraction of coals showed high reactivity (Sharma and Giri 2016; Renganathan et al. 1988). The gasification of SCC would solve the problem of hot gas clean up as this technology is not yet fully developed. Yang et al. (2015) have studied the $\mathrm{CO}_{2}$ gasification reactivity of a high ash coal, Nanlong coal $(39.06 \%)$ and reported that the gasification temperature had a huge effect on the reactivity of coal. The ash content in the coals greatly affected their gasification reactivity. The mineral matter contents in the coals also acted as catalyst to promote the gasification process. One such observation has been reported by Habibi et al. (2013) where an ash free coal was catalytically gasified using $\mathrm{K}_{2} \mathrm{CO}_{3}$ as the catalyst. Gasification using ash free coals would help in solving hot gas clean up problems and would also be helpful in the easier catalyst recovery (Gangwal et al. 1995; Park et al. 2006). The use of catalysts helps in reducing the temperature of gasification of coals (Furimsky 1984; Sharma et al. 1991).

Earlier scholars have reported on the development of a process of separative organo refining of coals using $\mathrm{N}$-methyl pyrrolidone containing smaller amount of ethylenediamine (EDA) or diethylenetriamine (DETA) (Pande and Sharma 2001; Dhawan et al. 2018; Dhawan and Sharma 2019). These separative organo-refining processes result in the production of SCCs having $0 \%-2 \%$ ash. In the present work, the $\mathrm{CO}_{2}$ gasification behaviour of a raw Indian low ash coking coal (i.e. Belbaid coal having $15.6 \%$ ash) and its SCC and residual coal (RC) obtained from the organo-refining using NMP containing a small amount of EDA or DETA has been studied. The action of the catalyst on the gasification behaviour and $\mathrm{CO}$ formation has also been studied at lower temperature $\left(900{ }^{\circ} \mathrm{C}\right)$. It was also important to study the $\mathrm{CO}_{2}$-gasification of the coal fractions obtained through separative-organo refining of coals under milder conditions for studying the thermal degradation behaviour of coal.

Solvent extraction of coal leads to the loosening and relaxation of coal structure especially in SCCs and RCs through the disruption and removal of intermolecular physical association forces (such as Van der waal forces, London forces, H-bondings, charge-transfer and $\pi-\pi$ interactions) as well as the dis-association of entanglements in the 3-dimensional cross linked polymeric gel network structure of coals. Therefore, it would be of great interest to study the $\mathrm{CO}_{2}$ gasification behaviour of the SCCs and RCs as against their raw coals. Studies were also extended to investigate the $\mathrm{CO}_{2}$ gasification behaviour of RCs along with sugarcane bagasse to enhance the $\mathrm{CO}_{2}$ gasification reactivity. In fact the coals were pre-pyrolysed to make these more reactive by generating active sites on their surface beyond those created through solvent action. The experiments were conducted in a fixed bed gasifier in $\mathrm{CO}_{2}$.

\section{Experimental}

\subsection{Experimental set up for gasification of coal}

The gasification activity of the coal samples and their SCCs and RCs was studied using a stainless steel fixed-bed reactor (Inner diameter $=8 \mathrm{~mm}$ ) at $900{ }^{\circ} \mathrm{C}$ temperature. The experimental set up used for the gasification studies has been shown in the Fig. 1. The laboratory gasifier was made up of stainless steel which could handle about 3-5 g of the coal sample (with and without catalyst). The initial part of the gasifier is composed of the electrically controlled heating system where the thermocouple was fitted for measuring the temperature of the coal bed. A heating rod was used to heat the sample in the coal bed reactant line. Before purging $\mathrm{CO}_{2}$ gas, the sample was pyrolysed using $\mathrm{N}_{2}$ (total flow rate $=40 \mathrm{~mL} / \mathrm{min}$ ) for $1 \mathrm{~h}$. The final mixture was fed into the reactor placed in a tubular furnace. The use of nitrogen as a standard was preferred for subsequent gas chromatographic analysis. The coal sample or the SCC or RC was kept between the quartz wool pieces at the middle of the reactor where the reaction temperature was maintained at $900{ }^{\circ} \mathrm{C}$. The gaseous products analysis quantitatively was performed using a gas chromatograph attached to TCD and Porapak Q and Molecular Sieve $13 \times$ columns in series. The quantitative determination of gaseous effluents was performed every $8 \mathrm{~min}$ with a total time of each run for $45 \mathrm{~min}$ to an hour. The gases produced 


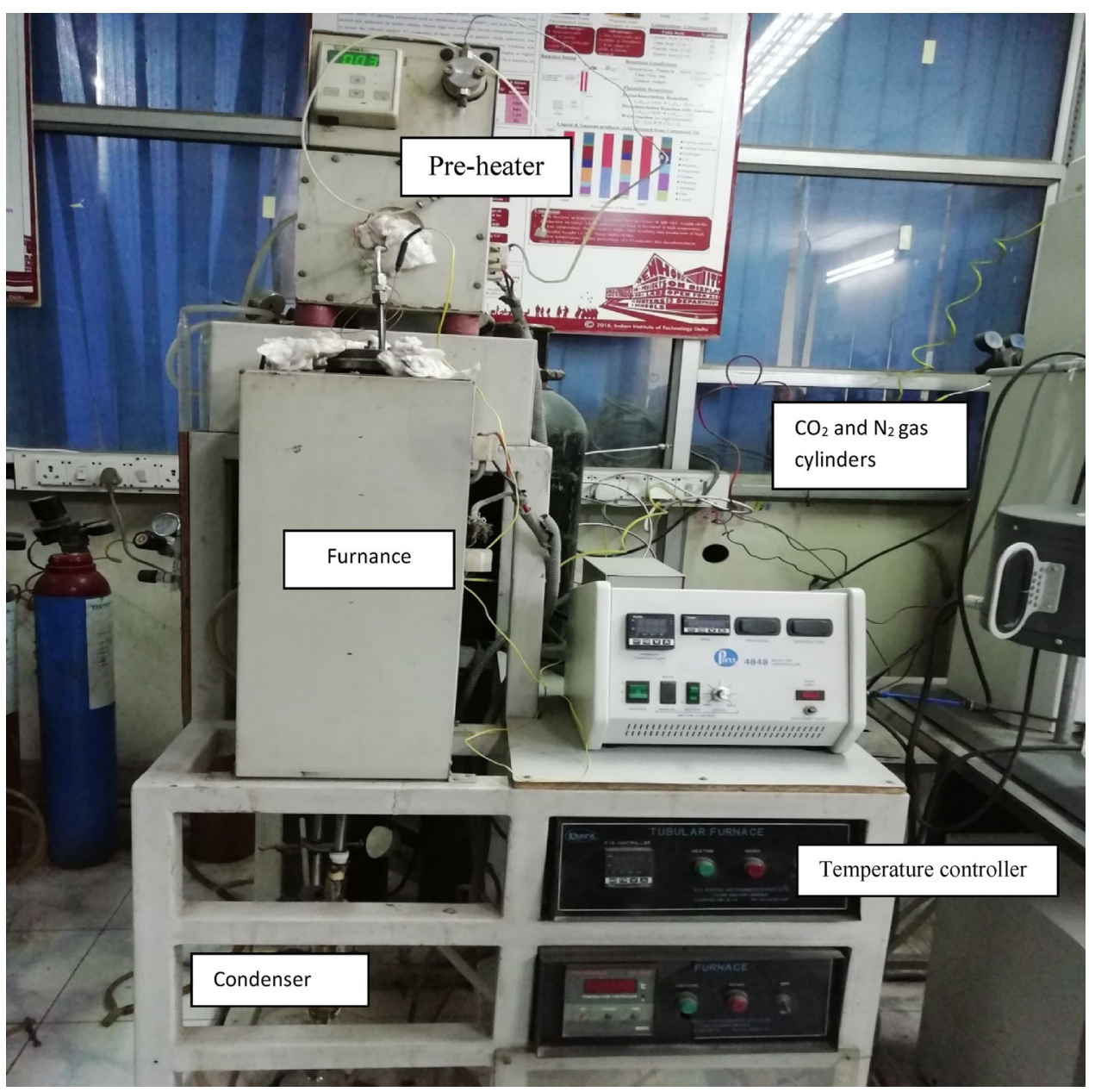

Fig. 1 Fixed bed reactor used for $\mathrm{CO}_{2}$-gasification

through the coal bed were collected at the bottom which were separated through the coolant.

\subsection{Experimental procedure}

The reactor was loaded with the coal sample ( $2.4 \mathrm{~g})$ and the catalyst $\left(\mathrm{K}_{2} \mathrm{CO}_{3}\right)(0.6 \mathrm{~g})$ was added in catalysed gasification reactions. The gasifier was thoroughly flushed with nitrogen in order to remove the oxygen present in the pyrolyser. Then the reactor was heated (electrically) (temperature was recorded using the calibrated thermocouple). The gases were purged at the rate: $40 \mathrm{~mL} / \mathrm{min}$ $\mathrm{CO}_{2}+40 \mathrm{~mL} / \mathrm{min} \mathrm{N}_{2}$ ). The gaseous products formed from the gasification were collected in the GC-MS through the syringe purged into the external tubing system. The reactor was maintained at about $900{ }^{\circ} \mathrm{C}$ for 45 min under $1 \mathrm{~atm}$ pressure conditions to constantly record the change in the gas composition (Table 1).

\subsection{Calculations for gasification rate and $\mathrm{CO}_{2}$ conversion}

Gasification rate (g/min) :

Coal(wt.)fed - Coal (wt.)after gasification total time of gasification (min s)

$\mathrm{CO}_{2}$ Conversion(\%) :

Volumetric flow rate of $\mathrm{CO}_{2} @$ inlet of reactor - Volumetric flow rate of $\mathrm{CO}_{2} @$ outlet of reactor Volumetric flow rate of $\mathrm{CO}_{2} @$ inlet of reactor 
Table 1 Proximate and ultimate analysis (wt\%) (on air dried basis) of Belbaid coal and bagasse

\begin{tabular}{|c|c|c|c|c|c|c|c|c|c|c|}
\hline \multirow[t]{2}{*}{ Coal/bagasse } & \multicolumn{4}{|c|}{ Proximate analysis } & \multicolumn{5}{|c|}{ Ultimate analysis (daf) } & \multirow{2}{*}{ Atomic $\mathrm{H} / \mathrm{C}$} \\
\hline & $M_{\mathrm{ad}}$ & $A_{\mathrm{d}}$ & $V M_{\text {daf }}$ & $\mathrm{FC}^{\mathrm{a}}$ & $\mathrm{C}$ & $\mathrm{H}$ & $\mathrm{N}$ & $S$ & $\mathrm{O}^{\mathrm{a}}$ & \\
\hline Belbaid coal & 3.6 & 15.3 & 39.4 & 41.7 & 65.7 & 4.2 & 1.6 & 0.2 & 28.3 & 0.95 \\
\hline Bagasse & 48.0 & 2.91 & 84.8 & 11.8 & 49.2 & 4.7 & 0.18 & 0.02 & 43.0 & 1.15 \\
\hline
\end{tabular}

${ }^{\mathrm{a} B y}$ difference

Table 2 Experimental conditions of $\mathrm{CO}_{2}$ gasification of coal

\begin{tabular}{ll}
\hline Sample & $\mathrm{CO}_{2}$-gasification conditions \\
\hline Gasification temperature & $700,800,900{ }^{\circ} \mathrm{C}$ \\
Amount of Belbaid coal (loading) & $2.4 \mathrm{~g}$ \\
Catalyst & $\mathrm{K}_{2} \mathrm{CO}_{3}$ \\
Catalyst loading & $0.6 \mathrm{~g}$ \\
Composition of gaseous feed mixture & $40 \mathrm{~mL} / \mathrm{min} \mathrm{CO}+40 \mathrm{~mL} / \mathrm{min} \mathrm{N} 2$ \\
Gasification run time & $45 \mathrm{~min}$
\end{tabular}

\section{Results and discussion}

Table 1 shows the proximate and ultimate analysis of Belbaid coal and Table 2 shows the experimental conditions used for the $\mathrm{CO}_{2}$-gasification of coal.

\subsection{Gasification of the raw coal with and without catalyst $\left(\mathrm{K}_{2} \mathrm{CO}_{3}\right)$}

The gasification of Belbaid coal was conducted at $900{ }^{\circ} \mathrm{C}$ in $\mathrm{CO}_{2}$ atmosphere for $45 \mathrm{~min}$. The gas composition was monitored using a GCMS for the generation of $\mathrm{H}_{2}, \mathrm{CO}$, $\mathrm{CO}_{2}$ gases. The gasification of the raw coal without the catalyst showed no $\mathrm{CO}$ formation for $45 \mathrm{~min}$. Even under inert conditions minor $\mathrm{CO}$ formation (Table 3) was observed from the raw coal when it was subjected to just pyrolysis at $650{ }^{\circ} \mathrm{C}$. The devolatilization and release of moisture contents was observed initially. The $\mathrm{CO}_{2}$ gasification process is extremely slow because of the reverse Boudouard reaction under atmospheric pressure conditions and at such low temperatures $\left(900{ }^{\circ} \mathrm{C}\right)$ is unfavourable, especially at temperatures below $600-700{ }^{\circ} \mathrm{C}$. When the catalyst was added, the gasification rate increased both for raw coal as well as in case of the SCCs. The results showed the significant improvement in the gasification rate and the carbon conversion (Table 4). The concentration of the catalyst used was almost $20 \mathrm{wt} \%$ of the weight of coal.

The reason for the difference in the gasification reactivity could be due to the active interaction of the potassium actions of the catalyst with the ash present in the raw coal in order for the gasification to take place at $900{ }^{\circ} \mathrm{C}$ in case of the raw Belbaid coal. The $\mathrm{H}_{2}$ formation takes place readily in case of SCCs as compared to that from the $\mathrm{CO}_{2}$ gasification of the raw coal. Most of this $\mathrm{H}_{2}$ is formed from the pyrolytic degradation of raw coal and SCCs. The catalyst $\mathrm{K}_{2} \mathrm{CO}_{3}$ being used proves as a hindrance due to the presence of kaolinite in the raw coal ash as proved by XRD studies. This interaction of $\mathrm{K}_{2} \mathrm{CO}_{3}$ with the kaolinite results in the formation of insoluble kaliophilite which further results in the loss of the catalyst (Wang et al. 2005; Formella et al. 1986). Moreover the insolubility results in kaliophilite deposition around the gasifier which might affect the overall efficiency of the gasification process. Negligible peak area of $0.47 \%$ due to CO formation was observed with the raw coal being used under inert conditions and when $\mathrm{CO}_{2}$ was purged and the flow started, the negligible conversion of $\mathrm{CO}_{2}$ to $\mathrm{CO}$ was noticed. The absence of steam results in the less formation of $\mathrm{H}_{2}$ gas and when the steam may be used along with $\mathrm{CO}_{2}$, then obviously the formation of $\mathrm{H}_{2}$ would increase. The high conversion of $\mathrm{CO}_{2}$ to $\mathrm{CO}$ in this case shows the ability of both the SCCs obtained after solvent extraction to be good feedstock for the production of $\mathrm{H}_{2}$ and synthesis gas.

The studies were further extended to use the SCCs and RCs obtained from the solvent extraction of Belbaid coal using NMP containing a small amount of EDA.

\subsection{Gasification of the SCCs obtained by using NMP containing small amount of EDA solvent system i.e. SCC $(e, N)$ and SCC obtained by using NMP containing small amount of DETA solvent system i.e. SCC (NMP-DETA)}

It was proposed to develop an integrated process of solvent extraction of coal to produce SCCs using two solvent 
Table 3 Formation of $\mathrm{CO}(\%)$ for the samples during $\mathrm{CO}_{2}$ gasification of coals

\begin{tabular}{llll}
\hline Sample & Catalyst & Temperature $\left({ }^{\circ} \mathrm{C}\right)$ & CO $(\%$ composition $)$ \\
\hline Raw Belbaid coal & - & 900 & 0.12 \\
Raw coal (with catalyst) & $\mathrm{K}_{2} \mathrm{CO}_{3}$ & 900 & 3.65 \\
SCC (NMP-DETA) & - & 900 & 6.42 \\
SCC (NMP-DETA) (with catalyst) & $\mathrm{K}_{2} \mathrm{CO}_{3}$ & 900 & 16.19 \\
SCC $(\mathrm{e}, \mathrm{N})$ & $\mathrm{K}_{2} \mathrm{CO}_{3}$ & 900 & 20.39 \\
RC & - & 900 & 2.27 \\
Bagasse & - & 900 & 2.74 \\
Raw + bagasse & - & 900 & 0.91 \\
RC + bagasse & - & 900 & 3.41 \\
SCC (NMP-DETA) $\left(70{ }^{\circ} \mathrm{C}\right)$ & - & 700 & 0.05 \\
SCC (NMP-DETA) $\left(800^{\circ} \mathrm{C}\right)$ & - & 800 & 0.06 \\
\hline
\end{tabular}

Table 4 Carbon conversion (gasification rate) and $\mathrm{CO}_{2}$ conversion during $\mathrm{CO}_{2}$ gasification

\begin{tabular}{lll}
\hline Sample & Gasification rate (carbon gasified/min) & $\mathrm{CO}_{2}$ conversion $(\%)$ \\
\hline Raw coal without catalyst & $0.005 \mathrm{~g}$ carbon $/ \mathrm{min}$ & 16 \\
Raw coal with catalyst & $0.018 \mathrm{~g}$ carbon $/ \mathrm{min}$ & 56 \\
Super clean coal without catalyst & $0.020 \mathrm{~g}$ carbon $/ \mathrm{min}$ & 48 \\
Super clean coal with catalyst & $0.036 \mathrm{~g}$ carbon $/ \mathrm{min}$ & 84 \\
\hline
\end{tabular}

systems-NMP containing a small amount of EDA (e, N) called SCCs (e, N) and NMP containing a small amount of DETA (NMP-DETA) called SCC (NMP-DETA) followed by gasification of the SCCs obtained. The peak in GC gives almost double the $\mathrm{CO}_{2}$ conversion for SCC (NMP-DETA) in comparison to that from the raw Belbaid coal. The $\mathrm{CO}_{2}$ gasification behaviour of the SCCs was found to be different from that of the raw Belbaid coal (Table 4).

Table 4 shows that the $\mathrm{CO}_{2}$ gasification reactivity (to form $\mathrm{CO}$ ) increase with an increase in the gasification temperature. Bouduard reaction mostly takes place at temperature above $600{ }^{\circ} \mathrm{C}$. The SCC generated with the use of a different solvent greatly affects the gasification reactivity. In one of the previous studies (Sharma and Giri 2016), one of the Indian coals, Samla coal was subjected to extraction in NMP, anthracene oil (AO) and cetene (CE) as solvents and the resulting SCCs obtained were gasified in $\mathrm{CO}_{2}$ at $900-1100{ }^{\circ} \mathrm{C}$ in a TGA apparatus. The reactivity order of the SCCs obtained through the extraction in these three solvents was found to be SCC-NMP > SCC-CE > SCC-AO. The reason for the high reactivity of the SCC extracted through NMP was the path adapted by NMP for the effective extraction of the organic matter from the coals. The high swelling of the coals in NMP and creation of channels and fissures in coal when subjected to dispersion in the solvent as reported through SEM images could be reason for such high reactivity. It was also reported for the e, N solvent system where NMP containing a small amount of EDA results in a product $(\mathrm{SCC}(\mathrm{e}, \mathrm{N}))$ by disruption of non-covalent interactions such as Van der waal forces, London forces, hydrogen bondings, $\pi-\pi$ interactions, charge-transfer interactions (Sharma and Dhawan 2018; Pande 2000). The use of DETA instead of EDA as a promoter/co-solvent for the solvent extraction to generate SCC (NMP-DETA) was found to affect the $\mathrm{CO}_{2}$ gasification reactivities. The gasification rate for $\operatorname{SCC}(e, N)$ was found to be more than that of the SCC (NMP-DETA). It seems the nature of the solvent used for the SCC extraction through NMP-DETA system and e, N system affects the gasification reactivity where the e, $\mathrm{N}$ extracted product shows the higher gasification reactivity as compared to SCC (NMP-DETA). The extra -NH over DETA may have resulted in more associations with the organic matter in coal as the extra donating group results in more effective association with the solvent thereby this may have resulted in less $\mathrm{CO}_{2}$ action on the SCC (NMP-DETA) as compared to that with $\operatorname{SCC}(e, N)$. 


\subsection{Gasification of the SCCs and the role of the catalyst $\left(\mathrm{K}_{2} \mathrm{CO}_{3}\right)$}

The use of ash free coal would help in avoiding the hindrance of the silicates and the aluminosilicates on the activity of the catalyst during gasification. This would also reduce the corrosion and erosion of reactor parts and this would also help in the recovery of the catalyst (for recycling) without its loss. The ash free coal would be fed to the reactor completely without leaving traces on the gasifier (Habibi et al. 2013; Formella et al. 1986). The role of the catalyst largely becomes more important from the study where the catalyst is found to be reduced and oxidised through an oxygen transfer cycle. The possible proposed mechanism behind this study is the formation of the -COK complex where the oxygen from the incoming gas, which is here $\mathrm{CO}_{2}$ can be used to transfer to the surface of the carbon thereby resulting in a KC complex (Long and Sykes 1950). It was proposed by Moulijn et al. (1984) and Freund (1986) that the role of the catalyst is to increase the gasification rate by improving the number of active sites and the oxygen on the surface without much affecting the kinetics of the process.

In fact, the SCC is more reactive in comparison to the OC (Sharma and Giri 2016) and the activity of the catalyst is not lost due to its reaction with coal ash, therefore, the immense increase in the conversion of $\mathrm{CO}_{2}$ to $\mathrm{CO}$ with the addition of the catalyst was observed. This shows the efficiency and effectiveness of the catalysed gasification of SCC which helps in the conversion of $\mathrm{CO}_{2}$ and more generation of CO. Some of the earlier studies have also reported on the action of the potassium catalysed reaction on the char surface of the coal. The formation of surface complexes as $\mathrm{C}-\mathrm{O}-\mathrm{K}$ and $\mathrm{C}-\mathrm{K}$ on the surface of the coal as the gasification proceeds was reported by Takarada et al. (1992). Another explanation for the potassium catalysed action on the coals was suggested by Wigmans et al. (1983) where the carbon reaction through the redox cycle was reported as the reason for the action of the potassium catalyst.

\subsection{Effect of temperature on the SCC (NMP-DETA) gasification}

Table 5 shows the effect of temperature on the gasification rate of the SCCs (with and without catalyst).

The $\mathrm{CO}_{2}$ gasification of SCC (NMP-DETA) of Belbaid coal was carried out at $700,800,900{ }^{\circ} \mathrm{C}$. In fact, the gasification of the raw coal was found to be better at $900{ }^{\circ} \mathrm{C}$ than that of the SCC (NMP-DETA) at $700{ }^{\circ} \mathrm{C}$ (Table 5). It could be due to the mineral matter present in the raw coal that gives the catalytic effect of the gasification at $900{ }^{\circ} \mathrm{C}$ (Yang et al. 2015). The moderate reactivity of the SCC (NMP-DETA) even at $700{ }^{\circ} \mathrm{C}$ could be due to the higher amount of the volatile matter in the SCC than in the raw coal. The gasification reactivity of the raw coal at $900{ }^{\circ} \mathrm{C}$ and the SCCs at different temperature was found to be in the order $\operatorname{SCC}\left(700{ }^{\circ} \mathrm{C}\right)<\operatorname{Raw}$ coal $\left(900{ }^{\circ} \mathrm{C}\right)<\mathrm{SCC}$ $\left(800{ }^{\circ} \mathrm{C}\right)<\mathrm{SCC}\left(900{ }^{\circ} \mathrm{C}\right)<\mathrm{SCC}\left(900{ }^{\circ} \mathrm{C}\right.$, with catalyst $)$. The role of the temperature in gasification could be the change in the proportion of the mineral matter in the SCCs where there could be difference in the mineral matter contents in the SCCs depending upon the differences in the solvent or solvent-cosolvent used when the same coal is used for extraction (Sharma and Giri 2016). The removal of the mineral matter through solvent extraction, the initial swelling in the solvents and then the extraction brings a change in the chemical constitution of the coal structure. Then the $\mathrm{CO}_{2}$ reactivity of the coals at different temperatures shows the different reactivity of the SCCs. More disruption of the coal structure at higher temperature results in improved reactivity when the temperature increased from 700 to $900{ }^{\circ} \mathrm{C}$ (Sharma and Giri 2016). Several researchers have reported that the carbon conversion increases with the increase in temperature. The production of the syngas increases with the oxidation and gasification reactions (Lahijani and Zainal 2011; Meng et al. 2011). Figure 2 shows the $\mathrm{GC}$ plot for $\mathrm{CO}_{2}$-gasification of raw Belbaid coalat $900{ }^{\circ} \mathrm{C}$.

\subsection{Gasification of residual coal (RC) at $900{ }^{\circ} \mathrm{C}$}

The Residual coal (RC) obtained after the e, $\mathrm{N}$ extraction was subjected to the $\mathrm{CO}_{2}$ gasification at $900{ }^{\circ} \mathrm{C}$. This showed $2.27 \%$ of $\mathrm{CO}$ formation in the product gas

Table 5 Carbon conversion (Gasification rate) and $\mathrm{CO}_{2}$ conversion during $\mathrm{CO}_{2}$ gasification

\begin{tabular}{lll}
\hline Sample & Gasification rate $(\mathrm{g}$ carbon gasified/min) & CO conversion $(\%)$ \\
\hline Super cleaned coal without catalyst @ 800 & 0.010 \\
Super cleaned coal without catalyst @ 700 & 0.003 & 25 \\
\hline
\end{tabular}




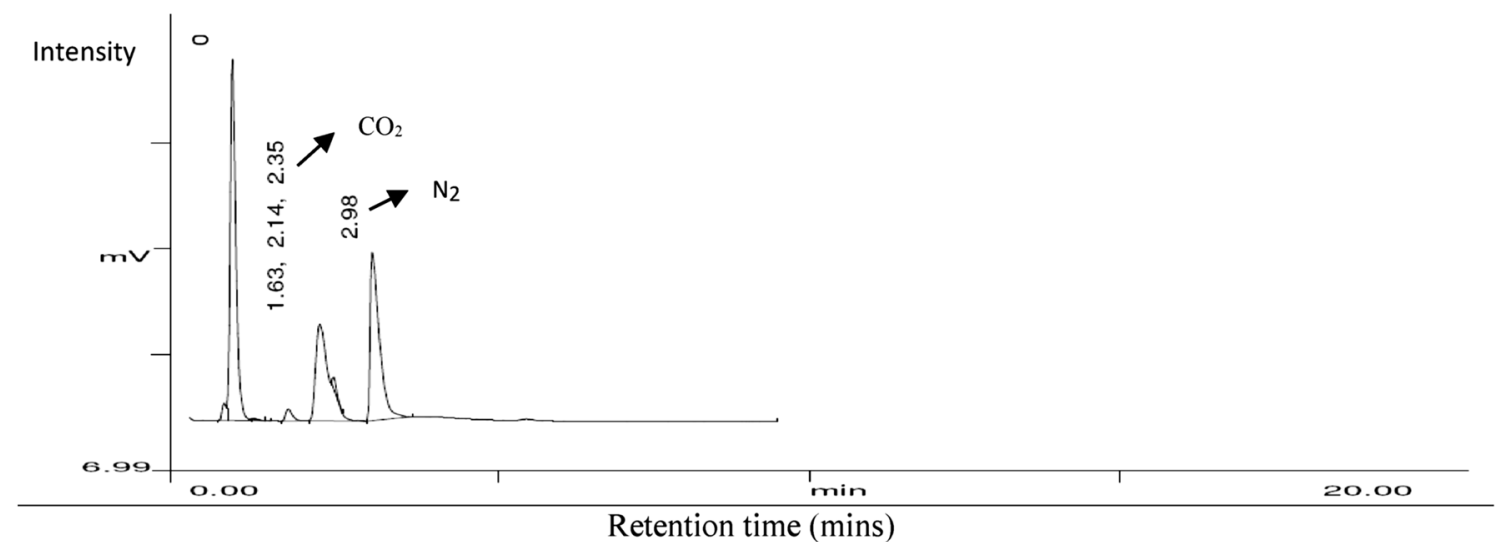

Fig. 2 GC plot of raw Belbaid coal $\left(900{ }^{\circ} \mathrm{C}\right)$

Table 6 Carbon conversion (Gasification rate) and $\mathrm{CO}_{2}$ conversion during $\mathrm{CO}_{2}$ gasification

\begin{tabular}{lll}
\hline Sample & Gasification rate $(\mathrm{g}$ carbon gasified/minute) & $\mathrm{CO}_{2}$ conversion $(\%)$ \\
\hline RC without catalyst & 0.008 & 28 \\
Bagasse without catalyst & 0.017 & 50 \\
RC + bagasse without catalyst & 0.011 & 36 \\
Raw + bagasse without catalyst & 0.006 & 20 \\
\hline
\end{tabular}

(Table 6). The carbon conversion was found to be $0.008 \mathrm{~g}$ $\mathrm{C} / \mathrm{min}$ and the $\mathrm{CO}_{2}$ conversion was $28 \%$ (Table 6).

The residual coal obtained after the extraction of the SCC from coal could prove to be a potential source for the utilization of the $\mathrm{CO}_{2}$ gasification. With the production of a premium quality ash free clean coal, the process leaves behind the residual coal which is high in mineral matter and low in organic matter content and thus this coal may not be desirable to be used directly for power generation. So this residue can be fruitfully used as a feedstock for gasification especially when the carbon contents in the RC increases after the recovery of SCC (Gerstner and Zondlo 1992). The extraction of coal may result in the enlargement of the pores with the continuous disruption of the intermolecular forces and non-covalent interactions in the coal. This may result in the increase in the active sites besides the increase in the internal surface area (Formella et al. 1986). Therefore, the residual coal showed better $\mathrm{CO}_{2}$ gasification reactivity than that of the raw coal. Moreover, after the extraction, the enhancement in the mineral matter content in the residual coal may provide good catalytic action thereby resulting in better reactivity. Gerstner and Zondlo (1992) and Sharma and Giri (2016) have carried out $\mathrm{CO}_{2}$ gasification studies on coal using TGA apparatus. According to Gerstner and Zondlo (Sharma and Giri 2016) the faster rate of the gasification of the residual coals obtained after extraction with NMP could be due to the increase in the active sites and the enhanced internal surface area which had resulted in the low activation energies and enhanced gasification rate of the coals. With no catalyst addition, the possible reason for the enhanced gasification in $\mathrm{CO}_{2}$ could be due to the catalytic action of mineral matter and the increase in the number of active sites on the residual coal. Thus, this enhanced gasification reactivity even in $\mathrm{CO}_{2}$ atmosphere may make the residual coals an interesting feedstock which are treated as a byproduct after the solvent extraction to be good feedstock for gasification and production of useful chemicals and fuels from residual coal such as methane, methanol, ethanol, nanofuels etc.

\subsection{Gasification of sugarcane bagasse (SGB) and bagasse and the raw Belbaid coal, blend and SGB and the residual coal blend at $900{ }^{\circ} \mathrm{C}$}

Biomass gasification is one of the most promising techniques to produce energy through high temperature catalytic and non-catalytic processes. Apart from the advantages that biomass offers of carbon neutral emissions and high availability it still shows some limitations of low energy values and very seasonal and geographical availability (Taba et al. 2012). Biomass produces large concentration of tars which can be useful in co-gasification with coals especially volatile matter lean $\mathrm{RC}$. The large 
production of tars even at intermediate temperatures can result in the overall good production of feedstock which when converted into their gaseous form can result in good syngas production. The main factors that contribute towards the production of the syngas during gasification are temperature, gas composition, pressure, nature of the carbon source used. Generally with increase in temperature, the $\mathrm{CO}$ formation increases as the water gas shift reaction and the Boudouard reactions increase with temperatures (Huang et al. 2003; Pohorelý et al. 2006; Fermoso et al. 2010). Since the amount of the organic matter in the RC had been removed, therefore, efforts should be made to increase the same by adding some other organic matter i.e. biomass. The major aim behind using bagasse along with residual coal was to increase the reactive organic matter in the $\mathrm{RC}+$ bagasse $(1: 1 \mathrm{wt} / \mathrm{wt})$ blend.

The use of bagasse here with residual coal offers the utilization of the carbon in the residual coal which when used with bagasse (containing higher volatile matter contents) can be used to generate syngas. According to the results obtained, bagasse shows better $\mathrm{CO}_{2}$ gasification as compared to the raw coal and the gasification rate is $50 \%$ more in bagasse than in the raw coal because of the high volatile matter content and loose mineral matter associations in biomass that may offer catalytic action during gasification. The enhanced reactivity of the biomass is the high amount of the volatile matter which forms free radicals much easier and thereby results in more oxidation, decomposition and gasification reactions. The higher contents of hydrogen and oxygen in biomass helps in high reactivity thereby resulting in high carbon conversion and CO formation (Taba et al. 2012). The use of residual coal along with biomass for $\mathrm{CO}_{2}$ gasification offers effective utilization of the residual coal and the moderate gasification rate shows the applicability of this coal-biomass blend as a potential gasification feedstock. The addition of bagasse to the residual coal shows much improved gasification reactivity as compared to the residual coal alone (Table 6). With the use of the residual coal-biomass blend, the overall gasification of the process improves with the subsequent increase in the volatile matter, availability of carbon from the residual coal and the overall increase in the mineral matter (of RC) that shows catalytic activity. The increase in the biomass concentration has been reported to have increased by Seo et al. (2010) in the gas yield due to the transfer of the hydrogen radicals from biomass to coal as the \% of the biomass was increased from $25 \%$ to $75 \%$ in the whole composition.

Present studies have shown that fractionation of coal through separative refining into SCC and RC offers the opportunity for enhancing the $\mathrm{CO}_{2}$ gasification of coals in comparison to that of RCs. Therefore separative refining of coal through solvent extraction is a beneficial technique for the gasification of coal especially by using $\mathrm{CO}_{2}$. In fact the SCCs, RC and raw coal were prepyrolysed presently so that their char could offer better reactivity towards the $\mathrm{CO}_{2}$ gasification of coals in comparison to that of the untreated coals, SCCs, bagasse (biomass). Thus, presently even the raw coal, SCCs and RCs were rendered reactive for $\mathrm{CO}_{2}$ gasification through prior pre-pyrolysis. Presently, no attempts were made to analyse the tar or other hydrocarbon gases as the major aim was the $\mathrm{CO}_{2}$ gasification for the formation of $\mathrm{CO}$ and carbon conversion. Further studies can be extended to carry out the $\mathrm{CO}_{2}+\mathrm{O}_{2}$ and $\mathrm{CO}_{2}$ $+\mathrm{H}_{2} \mathrm{O}+\mathrm{O}_{2}$ gasification of coals.

\subsection{Uses of SCC and RC}

These SCCs can be used fruitfully for production of fuels, chemicals, anodic cokes, co-combustion with biomass, plastics etc. (Song and Schobert 2002; Nag et al. 2018; Chang et al. 2014; Sharma and Dhawan 2018). These can also be blended with the original coals and used for cocombustion. Song and Schobert (2002) have reported various potential non-fuel uses of coal such as production of aromatic chemicals and advanced polymeric materials from coal. The use of SCC and coal for the production of CNTs and nanocomposites, carbon based materials such as carbon fibres, graphites and graphite based materials, metallurgical coke, fullerenes etc. has also been reported (Mathur et al. 2007; Dosodia et al. 2009; Bagotia et al. 2018). Solvent extraction of coal followed by beneficiation of the residue through specific gravity separation was developed by Mathur et al. (2007) and Choudhury et al. (1997). Though the use of certain elements such as Co, Y, $\mathrm{Ni}, \mathrm{Fe}$ act as catalysts in CNT production from coal, many other in ash hinder its production. It has been reported by Mathur et al. (2007) and Dosodia et al. (2009) that SCCs give better CNT yields and specific catalyst can be used more efficiently in CNT production. The presence of negligible ash in SCCs may improve the efficiency of various coal utilization processes. Not only just SCC, RC can be used for stepwise coal conversion or co-gasification with biomass. Sharma and Giri (2016) carried out steam pyrolysis of RCs at $650{ }^{\circ} \mathrm{C}$ to generate active chars. Their non-isothermal kinetic studies revealed that treatment of coals through organo-refining and steam pyrolysis was beneficial for gasification. Kinetics of the steam gasification under milder conditions of the OCs, RCs obtained after anthracene oil and liquid paraffin treatment and their chars have been studied by Sharma and Singh (1996) to design a reactor for steam gasification. Therefore SCCs and RCs offer huge applicability and further research work can be carried out in this area for coal structural determination and overall highly effective and cleaner coal utilization. There is a scope of using syngas in the reduction of iron ores in 
steel plants and in the liquefaction of coal through FischerTropsch and oxo-synthesis process.

Present studies have revealed that organo-refining is a beneficial separative refining process for generating clean coals (SCCs) and reactive coals (RCs). Thus, there seems to be a need for further developing organo-refining of coal processes. Some research work in this direction has been extended in the author's research laboratory and in the $R \& D$ centre of a steel plant having international operations. A pilot plant has been set up and several patents have been filed in efforts to make the process of organo-refining cost effective by researching inexpensive industrial solvents which may be recovered and recycled to the maximum extent (Chandaliya et al. 2012, 2013, 2015).

\subsection{Economizing the organo-refining of coals}

The major problem with the organo-refining of coals is the cost of solvents i.e., NMP, EDA, DETA, AO, CE etc. There is a need to either find out some more inexpensive solvent or develop a milder continuous process where almost 99.9\% solvent may be recovered and reused. Filtration of coal slurries or coal extracts may be easier as long as moderate extraction yields under ambient pressure conditions are processed. There is also a scope of using some other inexpensive solvents in the development of an economically attractive process using milder ambient pressure conditions (Dhawan et al. 2018; Dhawan and Sharma 2019). Advantages of using milder conditions over higher pressure at elevated temperatures in the solvent extraction of coal have already been discussed recently by Sharma and Dhawan (2018) and Dhawan and Sharma (2019). Therefore further research in this direction may lead to the development of an economical process of separative refining of coal through solvent extraction.

\section{Conclusions}

The studies on the $\mathrm{CO}_{2}$ gasification of raw coal, SCC (using two different solvent systems-NMP-DETA and e, $\mathrm{N})$ (with and without using catalyst), under different temperatures, $\mathrm{RC}$, bagasse along with $\mathrm{C}$ and raw coal led to the following conclusions:

(1) The action of the catalyst $\left(\mathrm{K}_{2} \mathrm{CO}_{3}\right)$ considerably increases the gasification reactivity of raw coal in $\mathrm{CO}_{2}$ which almost increases to three times with the addition of the catalyst $20 \%$ by weight.

(2) The solvent extraction of coal followed by the gasification of the SCC shows the applicability of the organo-refining process as in both SCCs $(\mathrm{e}, \mathrm{N})$ and SCC (NMP-DETA), they show good $\mathrm{CO}_{2}$ gasification reactivity at $900{ }^{\circ} \mathrm{C}$, much improved than that of the raw coal.

(3) The two SCCs produced using two different cosolvents showed different gasification reactivity showing the effect of variation in the nature of the solvents on the SCC production. SCC $(\mathrm{e}, \mathrm{N})$ was found to show better $\mathrm{CO}_{2}$ gasification behaviour than SCC (NMP-DETA).

(4) The much improved gasification behaviour of the residual coal over the raw coal shows the presence of more surface area or the active sites for the $\mathrm{CO}_{2}$ gasification to take place. RC has more mineral matter than the raw coal that may have helped in promoting the gasification reactions especially the Bouduard reaction.

(5) The improved $\mathrm{CO}_{2}$ gasification reactivity of $\mathrm{RC}$ and SCC over the raw coal shows the applicability of the solvent extraction process to generate two products (RC and SCC) through separative refining process that could serve as better feedstock for the gasification and utilization of $\mathrm{CO}_{2}$ as well.

Acknowledgements The authors would like to thank the Methanol project Grant No. TMD/CERI/MDME/2017/001(G) for providing the necessary funding.

Open Access This article is licensed under a Creative Commons Attribution 4.0 International License, which permits use, sharing, adaptation, distribution and reproduction in any medium or format, as long as you give appropriate credit to the original author(s) and the source, provide a link to the Creative Commons licence, and indicate if changes were made. The images or other third party material in this article are included in the article's Creative Commons licence, unless indicated otherwise in a credit line to the material. If material is not included in the article's Creative Commons licence and your intended use is not permitted by statutory regulation or exceeds the permitted use, you will need to obtain permission directly from the copyright holder. To view a copy of this licence, visit http://creativecommons. org/licenses/by/4.0/.

\section{References}

Adschiri T, Furusawa T (1986) Relation between $\mathrm{CO}_{2}$-reactivity of coal char and BET surface area. Fuel 65(7):927-931

Babaygit A, Thanh DD, Ethirajan A, Manca J, Muller M, Boyen HG, Conings B (2016) Assessing the toxicity of Pb- and Sn-based perovskite solar cells in model organism. Danio rerio 6:18721

Bagotia N, Chaudhary V,Sharma DK (2018) Review on improvement of mechanical, electrical properties and EMI shielding of polycarbonate nanocomposites carbon nanotubes and graphene, Ploym Adv Technol. In Press

Bai J, Li W, Li CZ, Bai ZQ, Li BQ (2009) Influences of mineral matter on high temperature gasification of coal char. J Fuel Chem Technol 37:134-138

Calemma V, Radovic L (1991) On the gasification reactivity of Italian Sulcis coal. Fuel 70:1027-1030 
Chandaliya VK, Banerjee PK, Biswas P (2012) Optimization of solvent extraction process parameters of Indian coal. Miner Process Extr Metall Rev 33:246-259

Chandaliya VK, Banerjee PK, Sharma DK (2013) A process flow sheet for pre-treatment of high ash coal to produce clean coal. World Patent Application WO2013136342 A1, September 19

Chandaliya VK, Biswas P, Banerjee PK (2015) Process for production of low ash clean coal from high ash coal with total solvent recovery. U.S. Patent Application 20150007494 A1, January 8

Chandaliya VK, Biswas PP, Dash PS, Sharma DK (2016) Producing low-ash coal by microwave and ultrasonication pretreatment followed by solvent extraction of coal. Fuel 212:422-430

Chang C, Whang T, Huang D, Wang D, Tsai S, Hung M (2014) Thermoplasticity and strength improvement of coking coal by addition of coal extracts. Fuel 117:364-371

Choudhury SB, Sarkar S, Chatterjee PK, Chatterjee SS, Prasad RR, Mukherjee SN, Ghosh SK, Rao SRK, Bose AN, Brahmachari BB, Haque R (1997) Solvent refined coal from high-ash non/ weakly coking coals for use in metallurgical coke making. Part II:utilization as a coking additive. Fuel Process Technol 51:165-176

Dhawan H, Sharma DK (2019) Refining of Indian coals to obtain ashless super clean coals having zero to insignificant amounts of deleterious elements under milder conditions. Miner Process Extr Metall. https://doi.org/10.1080/25726641.2019.1595310

Dhawan H, Upadhyayula S, Sharma DK (2018) Organo-refining to produce near zero ash coals: determination of elemental concentration in clean coals. Energy Fuels 32(6):6535-6544

Dosodia A, Lal C, Singh BP, Mathur RB, Sharma DK (2009) Development of catalyst free carbon nanotubes from coal and waste plastics. Fullerenes Nanotubes Carbon Nanostruct 17:567-582

Efthymia IK, Bergins C, Kakras E (2018) The $\mathrm{CO}_{2}$ economy; review of $\mathrm{CO}_{2}$ capture and reuse technologies. J Supercrit Fluids 132:3-16

Fermoso J, Gil MV, Arias B, Plaza MG, Pevida C, Pis JJ (2010) Application of response surface methodology to assess the combined effect of operating variables on high-pressure coal gasification for $\mathrm{H}_{2}$-rich gas production. Int $\mathrm{J} \mathrm{Hydr}$ Energy 35:1191-1204

Formella K, Leonhardt P, Sulimma A, van Heek KH, Juntgen H (1986) Interaction of the mineral matter in coal with potassium during gasification. Fuel 65:1470-1472

Freund $\mathrm{H}$ (1986) Gasification of carbon by $\mathrm{CO}_{2}$ : a transient kinetics experiment. Fuel 65:63-66

Furimsky E (1984) Gasification studies of Onakawana Lignite. Canad J Chem Eng 64(2):257-266

Gangwal S, Gupta R, McMichael W (1995) Hot-gas cleanup—sulfur recovery technical, environmental, and economic issues. Heat Recov Syst CHP 15(2):205-214

Gerstner JA, Zondlo JW (1992) Gasification of the residual coal produced from solvent extraction with $\mathrm{N}$-methyl pyrrolidone. Fuel Sci Technol Int 10(3):335-346

Grigore M, Sakurovs R, French D, Sahajwalla V (2008) Mineral reactions during coke gasification with carbon dioxide. Int $\mathrm{J}$ Coal Geol 75:213-224

Habibi R, Kopyscinski J, Masnadi MS, Lam J, Grace JR, Mims CA, Hill JM (2013) Co-gasification of biomass and non-biomass feedstocks: synergistic and inhibition effects of switchgrass mixed with sub-bituminous coal and fluid coke during $\mathrm{CO}_{2}$ gasification. Energy Fuels 27(1):494-500

Huang Y, Yamasita H, Tomita H (1991) Gasification reactivities of coal macerals. Fuel Process Technol 23:75-84

Huang J, Yitian F, Chen H, Wang Y (2003) Coal gasification characteristic in a pressurized fluidized bed. Energy Fuels 17:1474-1479
Huhn F, Klein J, Juntgen H (1983) Investigations on the alkalicatalysed steam gasification of coal: kinetics and interactions of alkali catalyst with carbon. Fuel 62:196-199

Kubiak H, Schroter HJ, Sulimma A, van Heek KH (1983) Application of $\mathrm{K}_{2} \mathrm{CO}_{3}$ catalysts in the coal gasification process using nuclear heat. Fuel 62:242-245

Lahijani P, Zainal ZA (2011) Gasification of palm empty fruit bunch in a bubbling fluidized bed: performance and agglomeration study. Bioresour Technol 102:2068-2076

Leung DYC, Caramanna C, Maroto-valer MM (2014) An overview of current status of carbon dioxide capture and storage technologies. Renew Sustain Energy Rev 39:426-443

Li CZ (2007) Some recent advances in the understanding of the pyrolysis and gasification behaviors of Victorian brown coal. Fuel 86:1664-1683

Li S, Cheng Y (1995) Catalytic gasification of gas-coal char in $\mathrm{CO}_{2}$. Fuel 74:456-458

Liu H, Luo C, Toyota M, Kato S, Uemiya S, Kojima T (2003) Mineral reaction and morphology change during gasification of coal in $\mathrm{CO}_{2}$ at elevated temperatures. Fuel 82:523-530

Long F, Sykes K (1950) The catalysis of the oxidation of carbon. J Chim Phys 47(3-4):361-378

Mathur RB, Lal C, Sharma DK (2007) Catalyst-free carbon nanotubes from coal-based material, part A: recovery, utilization, and environmental effects. Energy Sources Part A 29:21-27

Matsuoka K, Yamashita T, Kuramoto K, Suzuki K, Takaya A, Tomita A (2008) Transformation of alkali and alkaline earth metals in low rank coal during gasification. Fuel 87:885-893

Meng X, de Jong W, Fu N, Verkooijen AHM (2011) Biomass gasification in a $100 \mathrm{~kW} \mathrm{~h}$ steam-oxygen blown circulating fluidized bed gasifier: effects of operational conditions on product gas distribution and tar formation. Biomass Bioenergy 35:2910-2924

Moulijn JA, Cerfontain M, Kapteijn F (1984) Mechanism of the potassium catalysed gasification of carbon in $\mathrm{CO}_{2}$. Fuel 63(8):1043-1047

Nag D, Biswas P, Dash PS, Chandaliya VK, Sahoo PP, Saxena VK, Chandra S (2018) Characterisation and utilization of organorefined extract in metallurgical coke making. Int J Coal Prep Util 38:64-74

Nishiyama Y (1986) Catalytic behaviour of iron and nickel in coal gasification. Fuel 65:1404

Okuyama N, Komatsu N, Shigehisa T, Kaneko T, Tsuruya S (2004) Hypercoal process to produce ash-free coal. Fuel Process Technol 85:947-967

Pande S (2000) Studies on the ethylenediaamine assisted N-methyl pyrrolidone extraction of coal- scale up of the process and utilization of the super clean coal obtained, PhD Thesis, Indian Institute of Technology, New Delhi, India

Pande S, Sharma DK (2001) Studies of kinetics of diffusion of N-methyl-2-pyrrolidone (NMP), ethylenediamine (EDA), and $\mathrm{NMP}+\mathrm{EDA}(1: 1, \mathrm{vol} / \mathrm{vol})$ mixed solvent system in Chinakuri coal by solvent swelling techniques. Energy Fuels 15(5):1063

Park N-K, Lee D-H, Jun JH, Lee JD, Ryu SO, Lee TJ, Kim J-C, Chang CH (2006) Two-stage desulfurization process for hot gas ultra cleanup in IGCC. Fuel 85(2):227-234

Perez-Florind A, Cazoria-Amoros D, Linares-Solano A (1993) $\mathrm{CO}_{2^{-}}$ carbon gasification catalyzed by alkaline-earths: comparative study of the metal-carbon interaction and of the specific activity. Carbon 31:493-500

Pohorelý M, Vosecký M, Hejdová P, Puncochár M, Skoblja S, Staf M (2006) Gasification of coal and PET in fluidized bed reactor. Fuel 85:2458-2468

Renganathan K, Zondlo JW, Mintz EA, Kneisel P, Stiller AH (1988) Preparation of an ultra low ash coal extract under mild conditions. Fuel Proc Technol 18:273-278 
Schafer HNS (1991) Functional groups and ion exchange properties. In: Durie RA (ed) The science of Victoria brown coal: structure, properties and consequences for utilization. Butterworth-Heinemann Ltd, Oxford (Ch. 7)

Seo MW, Goo JH, Kim SD, Lee SH, Choi YC (2010) Gasification characteristics of coal/biomass blend in a dual circulating fluidized bed reactor. Energy Fuels 24:3108-3118

Sharma DK, Niwas S, Behera BK (1991) Solid state fermentation of bagasse for the production of cellulase enzyme from cellulolytic fungi and extent of simultaneous production of reducing sugars. J. Microb. Biotech 6:7

Sharma DK, Dhawan H (2018) Separative refining of coals through solvolytic extraction under milder conditions: a review. Ind Eng Chem Res 57(25):8361-8380

Sharma DK, Giri CC (2016) $\mathrm{CO}_{2}$ gasification reactivity and kinetics studies of raw coal, super clean coal and residual coals obtained after organo-refining (solvent extraction). J Power Technol 96(3):157-169

Sharma DK, Singh SK (1996) Multisolvent successive extractive refining of coal. Energy Sources 18:1-19

Sharma A, Takanohashi T, Morishita K, Takarada T, Saito I (2008) Low temperature catalytic steam gasification of HyperCoal to produce $\mathrm{H}_{2}$ and synthesis gas. Fuel 87:491-497

Sharma D, Rihko-Struckmann L, Sundmacher K (2011) Emerging need of studying quorum sensing and signal transduction in microalgae for boosting the product of biofuels from algae. In: 5th International Algae Congress 2011

Sharma DK, Dhawan H, Morgan T, Crocker M (2019) Py-GCMS studies of Indian coals and their solvent extracted products. Fuel 256:115981

Song C, Schobert HH (2002) Chemicals and materials from coal in the 21 st century. Fuel $81: 15-32$
Sun Q, Li W, Chen H, Li B (2004) The $\mathrm{CO}_{2}$ gasification and kinetics of Shenmu maceral chars with and without catalyst. Fuel $83: 1787$

Taba LE, Irfan MF, Daud WA, Chakrabarti MH (2012) The effect of temperature on various parameters in coal, biomass and $\mathrm{CO}$ gasification: a review. Renew Sustain Energy Rev 16:5584-5596

Takarada T, Ichinose S, Kato K (1992) Gasification of bituminous coal with $\mathrm{K}$-exchanged brown coal prepared from potassium chloride. Fuel 71:883-887

Tang LH, Wu YQ, Zhu XD, Zhu ZBJ (2002) Effect of char making temperature on char gasification activity in higher temperature. Fuel Chem Technol 30:16-20

Tomita A, Watanabe Y, Takarada T, Ohtsuka Y, Tamai Y (1985) Nickel-catalysed gasification of brown coal in a fluidized bed reactor at atmospheric pressure. Fuel 64:795-800

Wang J, Sakanishi K, Saito I, Takarada T, Morishita K (2005) Highyield hydrogen production by steam gasification of hypercoal (ash-free coal extract) with potassium carbonate: comparison with raw coal. Energy Fuels 19:2114-2120

Wigmans T, Elfring R, Moulijn JA (1983) On the mechanism of the potassium carbonate catalysed gasification of activated carbon: the influence of the catalyst concentration on the reactivity and selectivity at low steam pressures. Carbon 21(1):1-12

Yang Z, Zhang L, Peng J, Guo M (2015) Gasification of inferior coal with high ash content under $\mathrm{CO}_{2}$ and $\mathrm{O}_{2} / \mathrm{H}_{2} \mathrm{O}$ atmospheres. Int $\mathrm{J}$ Green Energy 12(10):1046-1053

Ye DP, Agnew JB, Zhang DK (1998) Gasification of a South Australian low rank coal with carbon dioxide and steam: kinetics and reactivity studies. Fuel 77:1209-1219

Yoshida T, Takanohashi T, Sakanishi K, Saito I (2002) Relationship between thermal extraction yield and softening temperature for coals. Energy Fuels 18:1006-1007 